\title{
NUMERICAL MODELLING OF THE STRENGTHENING PROCESS OF STEEL-CONCRETE COMPOSITE BEAMS
}

\author{
Piotr SZEWCZYK ${ }^{1}$, Maciej SZUMIGAŁA ${ }^{2}$ \\ ${ }^{1}$ West Pomeranian University of Technology, Faculty of Civil Engineering \\ and Architecture, Szczecin, Poland \\ ${ }^{2}$ Poznan University of Technology, Institute of Structural Engineering, Poznań, Poland
}

\begin{abstract}
This paper presents the numerical modelling of strengthening a steel-concrete composite beam. The main assumption is that the strengthening is not the effect of the state of a failure of a structure, but it resulted from the need to increase the load-bearing capacity and stiffness of the structure (for example: due to a change in the use of the object). The expected solution is strengthening without the necessity to completely unload the structures (to reduce the scope of works, the cost of modernization and to shorten the time). The problem is presented on the example of a composite beam which was strengthened through welding a steel plate to the lower flange of the steel beam. The paper describes how energy parameters are used to evaluate the efficiency of structures' strengthening and proposes an appropriate solution.
\end{abstract}

Keywords: Finite element method, composite beams, strengthening, non-linear analysis

\section{INTRODUCTION}

The subject of the paper is a detailed analysis of the effectiveness of the strengthening process of steel-concrete composite beams. For a designer, strengthening of a structure is often a much more difficult task than designing a new structure. The level of difficulty additionally increases when we deal with a structure consisting of two materials that differ significantly in terms of

1 Corresponding author: West Pomeranian University of Technology, Faculty of Civil Engineering and Architecture, Al. Piastów 50, 70-311 Szczecin, Poland, e-mail: szewczyk@zut.edu.pl 
mechanical properties, such as e.g. ductile steel and brittle concrete. Therefore, this kind of problem, combining problems known from the strengthening of traditional steel structures and classical reinforced concrete structures became the object of interest of the authors. It was assumed in this paper that the analysed beams were part of a building and engineering structures excluding bridges, and therefore it was possible to extend the analysis to the plastic range. This assumption, by taking into account the redistribution of stresses between components, significantly increases the efficiency of the whole process of strengthening. It was also assumed that the strengthening was not the effect of the state of failure of the structure but it resulted from the need to increase the load-bearing capacity and stiffness of the structure e.g. due to a change in the use of the object. In such a situation it is important from the point of view of an investor that the modernised facility is excluded from the operation for as short time as possible and the scope of works is as small as possible. Therefore, the paper analyses the possibility of strengthening the structure with its partial loading up to the value of permanent load and a part of imposed loads.

\section{NUMERICAL MODELLING}

\subsection{Composite beam}

The above problem was analysed based on the example of a series of simply supported composite beams with lengths from 4 up to 8 meters. A general view of the adopted models is shown in Fig. 1.

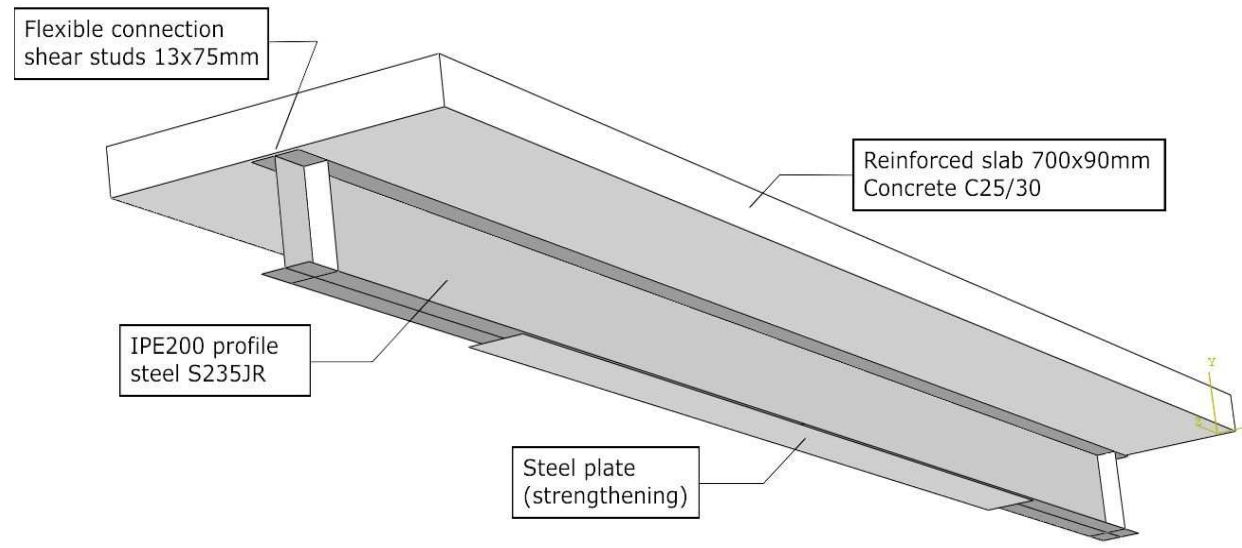

Fig. 1. General view of the analysed model 
The same cross-section was a common feature of the beams. A slab with the dimensions of $700 \times 90 \mathrm{~mm}$ was designed of C25/30 concrete and reinforced with two meshes made of $\square 8 \mathrm{~mm}$ bars. The steel beam was formed of IPE200 rolled section made of S235JR steel. The connection was obtained with the use of $\mathrm{K} \square \mathrm{CO}$ SD shear studs with the size of $13 \times 75 \mathrm{~mm}$. The beam with the length of 5 metres was also made physically as an experimental model, aiming at verifying the created numerical model. Four identical beams were made, which then would be strengthened in such a way as to obtain about a 50\% increase in the load-bearing capacity. Fig. 2 shows the testing facility with the first of the analysed beams.

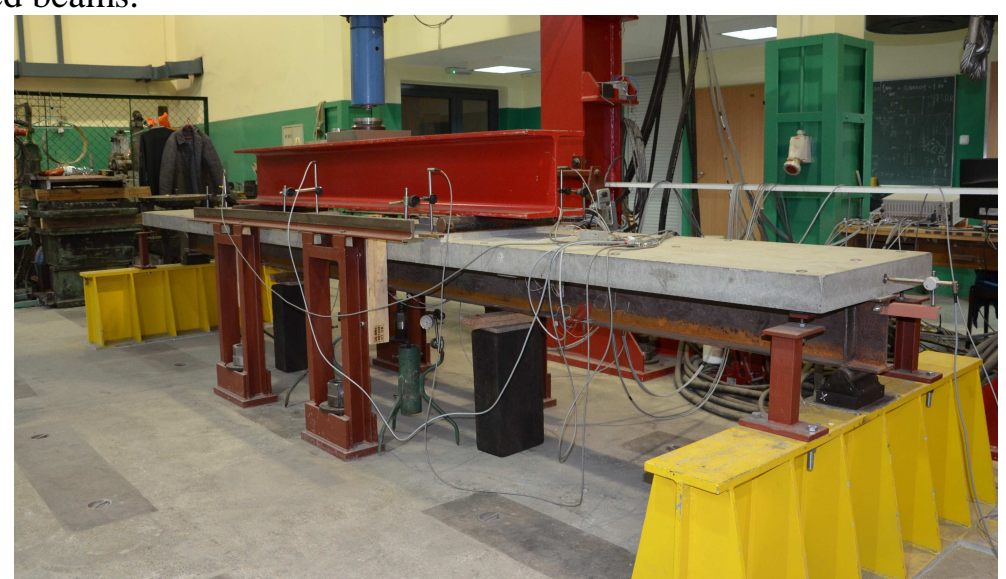

Fig. 2. The testing facility with the first of the analysed beams

\subsection{Materials}

The conducted numerical analyses included the linear elastic range of the beam performance during which strengthening took place as well as non-linear range covering plasticising and destruction of the element. For this reason an attempt was made to more accurately describe the physical laws of the materials used. A series of material tests were carried out, starting from typical standard testing and ending with advanced strain gauging. The steel was modelled as an elasticplastic material with a yield point and strain hardening (three-line model). The concrete was described using Concrete Damage Plasticity Model [1], which allows description of the behaviour of the concrete both in compression and tension. Fig. 3 shows images of example material testing and finally obtained material model parameters. 

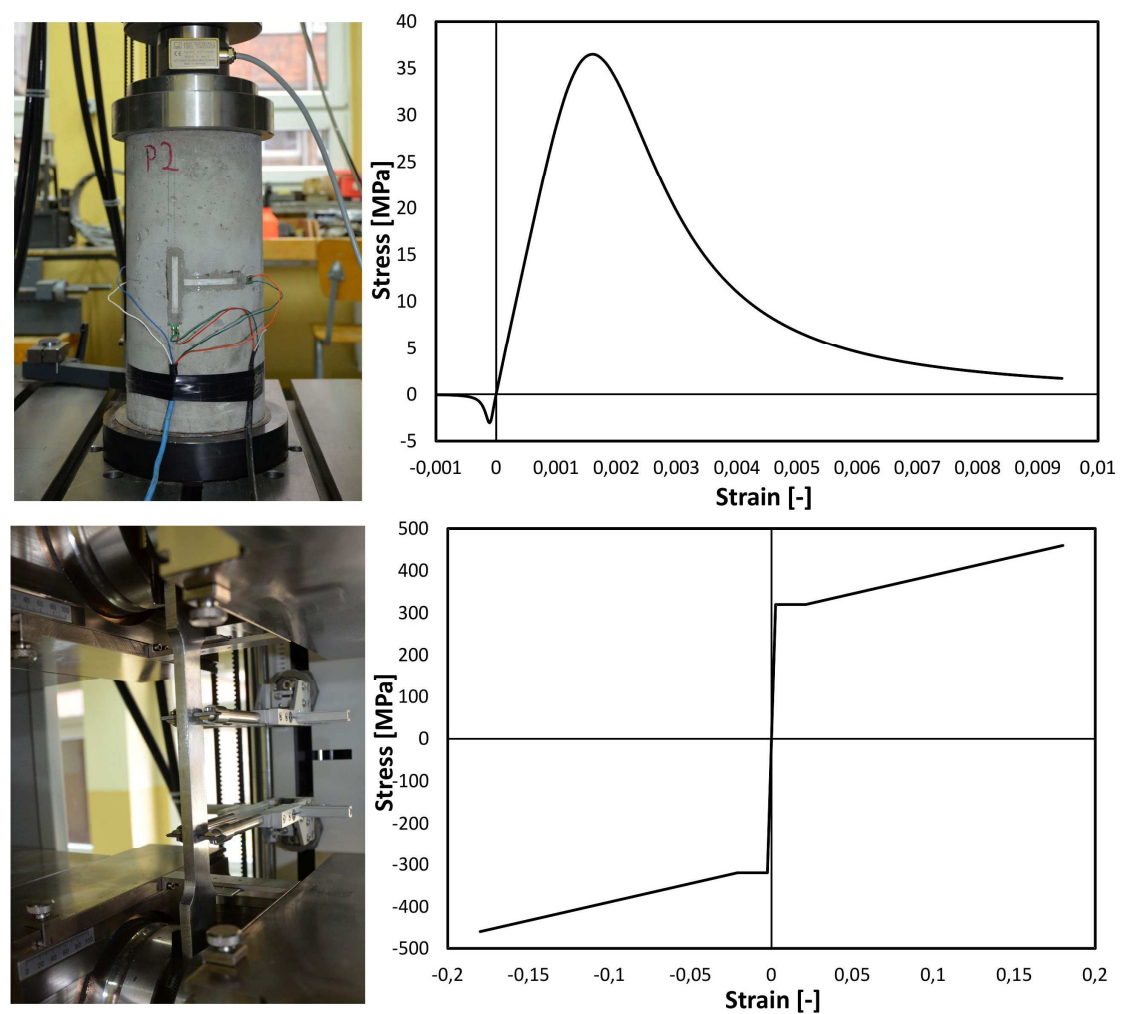

Fig. 3. Physical laws of materials

\subsection{Selected aspects of modelling}

Based on the above assumptions numerical models of the analysed beams were created in the Abaqus/CAE software. They are precise, spatial, threedimensional models, taking into account the material and geometric nonlinearities. Figure 4 shows a view of the discrete model broken down into individual elements. An important part of the model is the beam elements mounted on the upper flange of the I-section with the dimensions and spacing identical to the shear studs used in practice. These elements were "embedded" in the reinforced concrete slab, which enabled representation of the practically executed flexible shear connection. A similar technique was used in the embedding of the reinforcement mesh in the concrete slab. Although the reinforced concrete slab is compressed as an assumption but the reinforcement used here fulfils a coupling function, clearly reducing the tensile stress state in the concrete in the surrounding of the shear studs. An evenly distributed load was applied in all numerical analyses. 


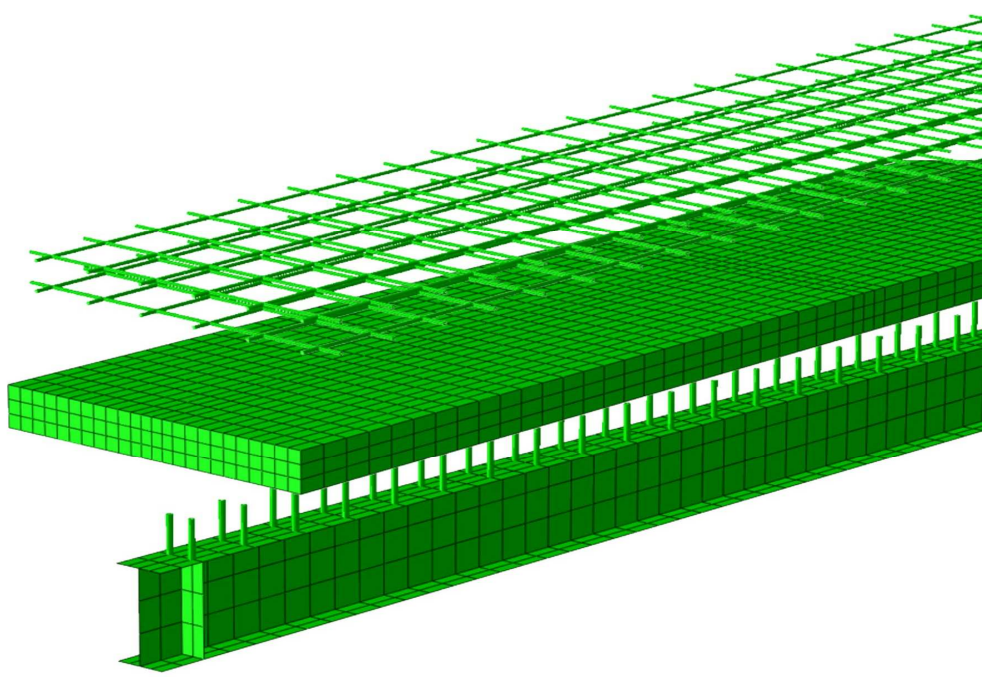

Fig. 4. Discrete model of the composite beam

\section{SIMULATION OF THE STRENGTHENING PROCESS}

Increase in the load capacity and stiffness of the composite beam can be effected in many ways. It is possible to enlarge the surface of the tensed steel section or the compressed concrete part as well as to change the static graph, e.g. by making continuous a series of individual beams. Enlargement of the cross-sectional area can be carried out by adding a material having the same properties as the base material i.e. respectively through welding on of a steel plate or a rolled section or by placing of an additional layer of a concrete overlay unit adequately connected with the original reinforced concrete slab. Very good results can also be achieved by using carbon tapes (CFRP) that are more and more popular in the construction industry, which was shown in many publications, e.g. [4]. The choice of the method may depend on many factors beyond the control of the designer such as the access to the structural elements or the possibility to carry out construction works. However, if such restrictions do not exist, we may carefully analyse which option is more advantageous. The analysed beam was designed so as the elastic neutral axis is at the height of the plane of the connection, allowing for the best use of the embedded material. The neutral axis within the plastic range moves in the direction of the reinforced concrete slab, and therefore the beam cross-section adopted in the tests determines the usefulness of strengthening by increasing the steel part of the cross-section. The strengthening was accomplished through welding a steel 
plate to the lower flange of the steel beam (Fig.5). For technological reasons to allow welding in the flat position - the width of $120 \mathrm{~mm}$ was assumed for the strengthening plates (the width of the I-section flange is $100 \mathrm{~mm}$ ). The thickness of the plate and its length and totally - the weight and the costs became variables in the conducted parametric analysis.

evenly distributed load

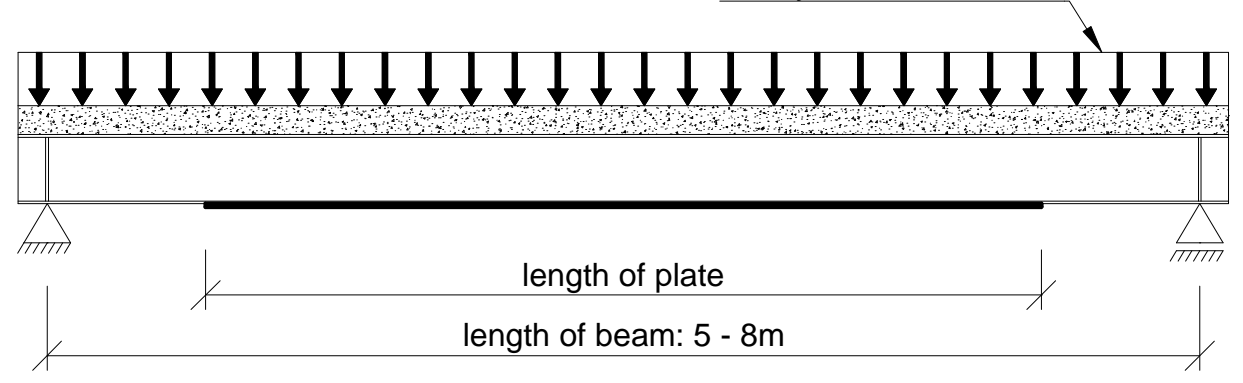

Fig. 5. The static scheme of the analysed beams

The paper also includes the possibility of strengthening in the situation of a partial structure effort, which is not a typical engineering practice. Such a way of strengthening can significantly shorten the time and reduce the costs of execution of construction works. While deciding for the strengthening of the structure under load, a question arises: at which load level should it be done and how will it affect the effectiveness of the executed works? It is possible to carry out strengthening under full load or with application of partial relief. It is also possible to use of special "active supports" aiming at reduction of the deflection value and even to introduce a small reverse deflection prior to strengthening [2]. Fig. 6 shows example static equlibrium paths for each of the described solutions (for the $5 \mathrm{~m}$ beam strengthened by the $3,2 \mathrm{~m}$ length and $10 \mathrm{~mm}$ thickness plate). Starting from the introduction of the reverse deflection through comparable graph without load up to the strengthening at different load levels it is clear that the load value at the time of strengthening does not affect the ultimate limit state of the strengthened structure. On the other hand, the operations presented above clearly affect the value of deflection of the strengthened element. Thus, taking into account the serviceability limit state these operations are highly justifiable. In the depicted static equlibrium paths there is a clear point where the strengthening takes place. From this point a significant increase in the structure stiffness is clearly seen as shown by the increase in the angle of the graph inclination with respect to the axes of displacement. 


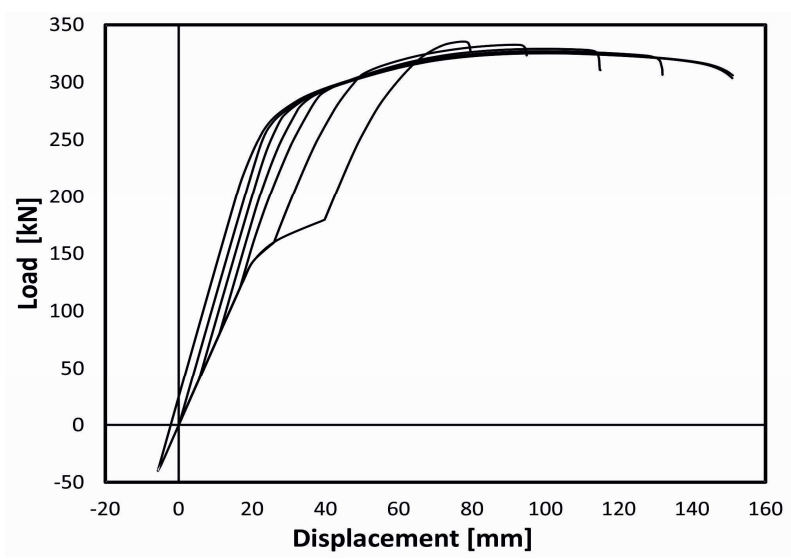

Fig. 6. Static equlibrium paths for different load levels during strengthening

The aim of the conducted analyses was to obtain a solution that maximises the load-bearing capacity and stiffness of the structure using the minimum required amount of the material additionally embedded into the structure. For this purpose, the impact of the thickness and the length of the strengthening plate on the variability of the two parameters obtained through the FEA simulation in the Abaqus software was analysed, i.e. the load-bearing capacity of the strengthened beam and the values of the elastic strain energy.

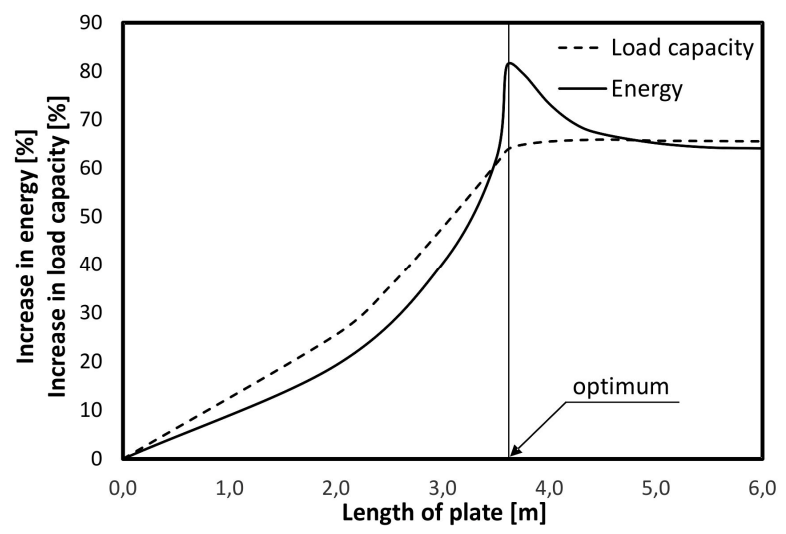

Fig. 7. Variation of energy and load capacity for a 6 metre-long beam strengthened with plates of different lengths

Fig. 7 shows an example variation of these parameters for a 6 metre-long beam strengthened with plates of different lengths with the thickness of $10 \mathrm{~mm}$. The clearly visible energy extreme coincides with reaching the maximum loadbearing capacity of the beam. The increase in the length of the plate above the length corresponding to the energy extreme does not increase the load-bearing 
capacity or even prevents the redistribution of stresses between the strengthened and the strengthening elements. In this case, the energy parameter is proposed as a measure of an optimum solution for the strengthened beam. The correctness of the adopted parameter is shown in more detail in the [3] paper.

\section{RESULTS}

The analysis of the variability of the elastic strain energy shown in Figure 7 was carried out for different lengths of the beams of 4, 5, 6, 7 and 8 metres. Plates with the thicknesses from 6 up to $30 \mathrm{~mm}$ and the lengths from 30 up to $100 \%$ of the beam span were taken into account. Totally, more than 700 computation models were considered. An example graph of energy variation for the 6 metre long beam strengthened with plates of all thicknesses and lengths under consideration is shown in the Figure 8.

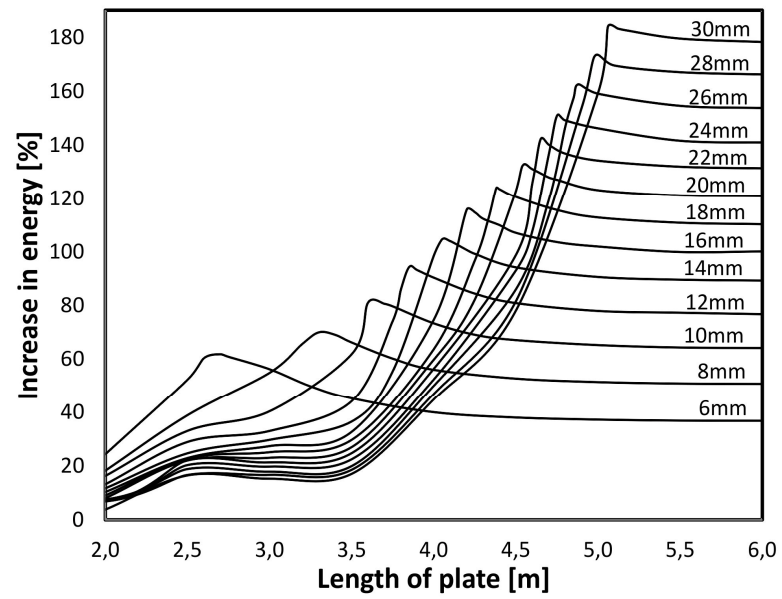

Fig. 8. Energy increase against the length of the plate for various thicknesses of the 'plate

The presented graph shows that the location of the optimum solution, i.e. the energy extreme depends on the thickness of the strengthening plate. The increase in the thickness of the plate makes it necessary to use it with a greater length to obtain the optimum solution. Based on this graph a curve can be plotted, defining the dependence of the optimum solution on the two variables of the conducted analysis: the length and thickness of the plate. The summary breakdown of the results obtained for all the analysed lengths of the beams is shown in Fig. 9. Unfortunately, for the shortest beams it was not possible to obtain solutions for all plate thicknesses. With the increase in the thickness of the plates the sought extreme becomes less and less clear. Adoption of a plate 
thicker than $18 \mathrm{~mm}$ for 4 metre long beam and $24 \mathrm{~mm}$ for the 5 metre long beam results in the lack of extreme. For beams with the lengths of 6 to 8 metres the plate thicknesses greater than $30 \mathrm{~mm}$ were not considered as welding of such plates with fillet weld would be difficult from the technological point of view.

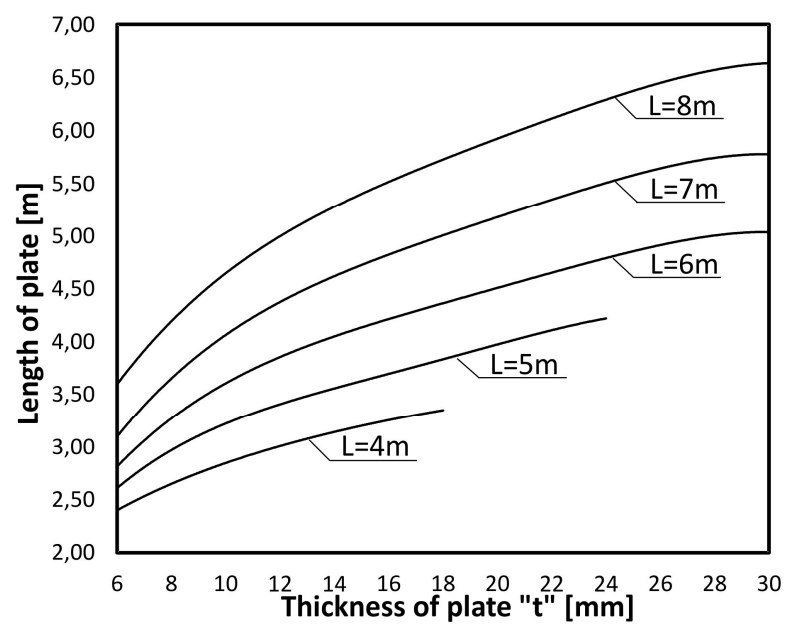

Fig. 9. Optimal dimensions of the strengthening plate for different lengths of the beam

The analysis in Fig. 9 shows an obvious need for the use of longer plates with beams of a larger span. However, referencing the lengths of the plates to the beam span (Fig. 10) shows that this dependence is not linear. It is clear that shorter beams require the use of relatively longer plates.

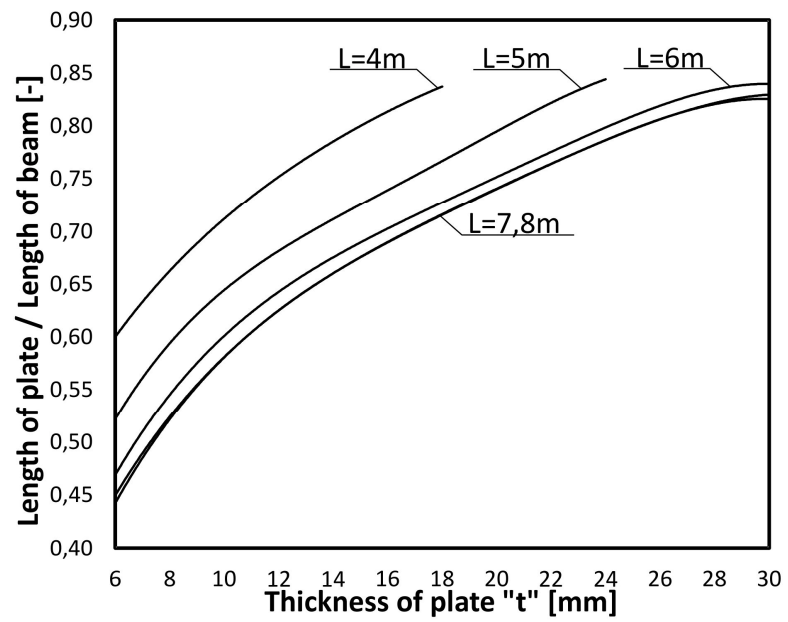

Fig. 10. Optimal dimensions of the strengthening plate for different lengths of the beam 
On the other hand, with increase in the length of the beam the optimum solution begins to reach a certain constant level, which in this case was reached with beams 7 and 8 metres long.

It should also be noted that in each of the analysed cases, the use of plates with the lengths of more than $85 \%$ of the beam does not bring measurable advantages. The obtained results are even more evident in the following figure (Fig. 11).

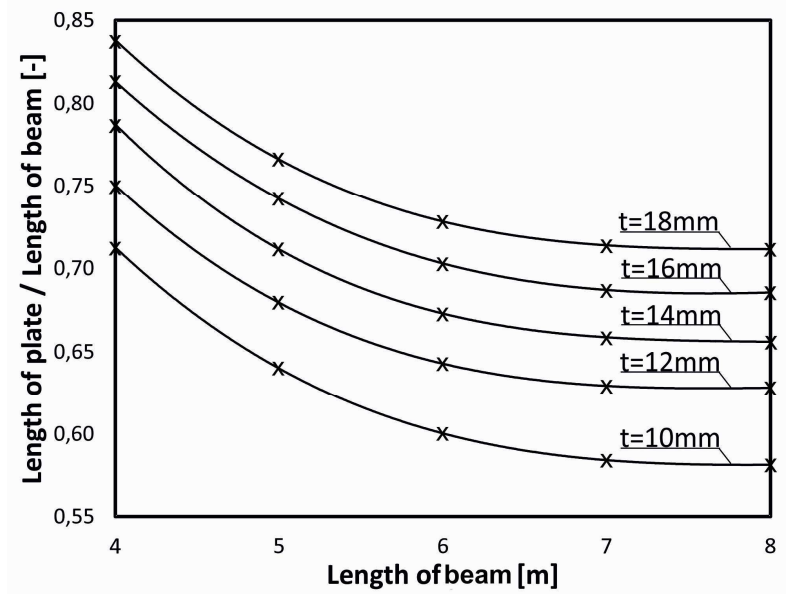

Fig. 11. Curves of the desired length of the plate depending on its thickness

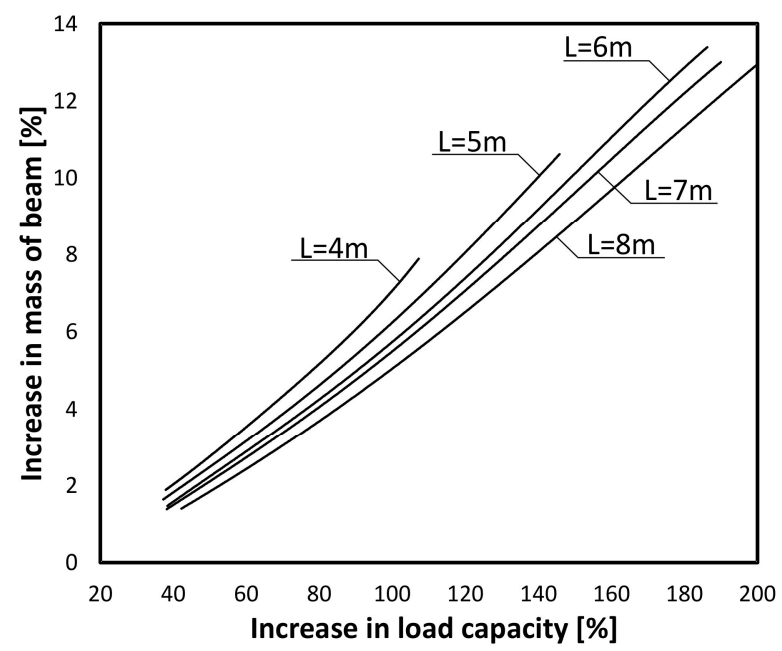

Fig. 12. Relation between the increase in the load-bearing capacity and the increase in the mass of the strengthened beam 
It includes examples of curves of the desired length of the plate depending on its thickness. A clear increase in the required length of the strengthening plate is clearly seen here for the shortest analysed beams.

The obtained results translate into a specific amount of steel needed to be embedded into the modernised facility. This relationship is shown in Fig. 12 as the relation between the increase in the load-bearing capacity and the increase in the weight of the strengthened beam. The figure shows a clear trend indicating that it is the longest beams that are best able to "use" the newly embedded material. At the same level of the increase in weight, each additional longer beam shows greater increase in the load-bearing capacity.

\section{CONCLUSIONS}

During preparation of a design of strengthening of a building facility one should consider carrying out the works with partial effort of the structure, which can reduce the time and the costs of investment and does not affect the final loadbearing capacity of strengthened element. Also the dimensions of the strengthening elements are worth careful examination. The optimum size of the plate is a function of many variables. The result also depends, inter alia, on the thickness and the length of the plate used and the relative proportion of the beam length to its cross section. The use of elements which are too short can significantly reduce the expected effect of strengthening; use of parts which aretoo long does not bring the expected result either. In the analysed cases, the optimum lengths of the plates were within the range of 45 to $85 \%$ of the length of the strengthened beam.

\section{REFERENCES}

1. Abaqus User's Manual. Version 6.9, USA 2009.

2. Szumigała M., Szewczyk P.: The numerical modeling of strengthening the structures under load, Scientific Bulletins of Rzeszów Uniwersity of Technology, number 59 (3/12/II) Rzeszów 2012.

3. Szumigała M., Szewczyk P.: The trial of optimal strengthening of composite beams, Recent Advances in Computational Mechanics, Taylor \& Francis Group, London 2014.

4. Marcinowski J, Błażejewski P.: Strengthening of steel rods and shell structural by using external layers made of carbon fiber polimer, „Composite Structures 2014” Zielona Góra, 26-27.06.2014. 


\section{NUMERYCZNE MODELOWANIE PROCESU WZMACNIANIA STALOWO-BETONOWYCH BELEK ZESPOLONYCH}

\section{Streszczenie}

Przedmiotem pracy jest analiza numeryczna przebiegu procesu wzmacniania stalowobetonowej belki zespolonej. Podstawowym założeniem jest, że konstrukcja nie znajduje się w stanie awaryjnym, lecz wzmocnienie ma na celu zwiększenie jej nośności i sztywności w trakcie użytkowania obiektu (np. ze względu na zmianę sposobu użytkowania). Poszukiwanym rozwiązaniem jest wzmacnianie bez konieczności pełnego odciążenia konstrukcji, co skracałoby czas, zmniejszało zakres robót oraz obniżałoby koszty modernizacji. Wzmacnianie zostało zrealizowane poprzez dospawanie stalowego płaskownika do pasa dolnego profilu stalowego. W pracy przedstawiono zastosowanie parametrów energetycznych przy ocenie efektywności procesu wzmacniania konstrukcji i doborze optymalnego rozwiązania.

Słowa kluczowe: Metoda Elementów Skończonych, belki zespolone, wzmacnianie, analiza nieliniowa

Editor received the manuscript: $17.12 .2014 \mathrm{r}$. 